\title{
Feminist Thought and Gender Theology
}

\author{
Silvia Senjaya ${ }^{1}$, Alifiulathin Utaminingsih ${ }^{2}$ \\ \{silviathe78@student.ub.ac.id $\left.{ }^{1}\right\}$ \\ Universitas Brawijaya, Indonesia ${ }^{1,2}$
}

\begin{abstract}
Interdisciplinary, intersectional, and interlocking are the kind of adjectives that best describe the way we feminists think. That is why I want to study gender-related issues from a theological perspective. There are differing views on gender theory from the perspective of sociologists and theologians. Sociologists tend to refer to the Nurture Theory where the distinction of relations between men and women is not determined by biological factors and divine nature alone but by the formation and construction of society that it is not universal and interchangeable. Whereas theologians tend to refer to the belief that gender roles are regulated by God by nature and are not negotiable as the Theory of Nature says. For centuries theologies produced and formulated into dogmas/churches and practised in the church, life is discussed by the thoughts, feelings, experiences, struggles, and hopes of men who are highly androcentric of patriarchal culture. Many texts in the Bible state that women are sub-ordinate of men. This interpretation is then constructed and socialized by religious institutions and family institutions as God's provisions regarding gender roles. The position and role of women as a sub-ordinate result in injustice and marginalization of women in patriarchy culture. This study examines the interpretation of theological assumptions regarding gender, inequality, and marginalization of women, the feminist thought and men social reaction.
\end{abstract}

Keyword: Feminist, Gender, Patriarchy, Theology.

\section{Introduction}

Since writing her first introduction to feminist thought nearly two decades ago, Rosemarie Tong becomes increasingly convinced that feminist thought resists categorization into tidy schools of thought [1]. Interdisciplinary, intersectional, and interlocking are the kind of adjectives that best describe the way we feminists think. That is why I want to study genderrelated issues from a theological perspective.

The history of gender roles between men and women through a very long process. Gender differences are formed, constructed and socialized socially, culturally, politically by family institutions, tradition institutions, government institutions, and religious institutions. By religious institutions, through the interpretation of theological assumptions, the construction of gender roles is considered to be a non-negotiable provision of God.

Gender roles do not really matter as long as they do not result in injustice and marginalization. Gender injustice is a system and structure in which both women and men become victims of injustice that is built based on the differentiation of men and women. Gender injustice can be manifested in real terms in the form of economic marginalization, political rights, and violence. Injustice can also be manifested abstraction through stereotypes or negative labelling and inequality where placement occurs as ordinate-subordinate in relations or hierarchy based on gender. 


\section{Research Method}

The research methodology used is qualitative with literature research. The object of research material is thoughts, concepts, ideas and theories from feminists and sociologists related to gender. Whereas formal objects are seen from the point of view of interpreting biblical theology. Research data sources are the literature on gender, feminists and theology related to gender.

\section{Results and Discussion}

\subsection{Gender-Based on Bible Theology}

'Sex' is generally used to identify anatomical differences between male and female especially based on genitals. Whereas the word 'gender' was first introduced by Robert Stoller in 1968 in his book Sex and Gender. Stoller uses the word 'gender' to separate human traits based on defining socio-cultural and socio-cultural definitions with definitions derived from biological physical features [2].

Alifiulahtin Utaminingsih [3] explains that there are three theories about gender, namely:

a) Theory of Nature, explains that the difference in roles between men and women is natural and so that they cannot be exchanged.

b) Theory of Nurture, the distinction of relations between men and women is not determined solely by biological factors but rather by the formation and construction of society.

c) Equilibrium Theory, emphasizing the balance, partnership, and harmony between men and women.

In social science, the person who is developing gender terms and understanding is Ann Oakley. She was one of the first social scientists to distinguish the concept of gender from the concept of sex. As quoted by Amy Blackstone in Gender Roles and Society, Oakley defines gender as a social construction or attribute imposed on humans that are built by human culture. According to Oakley, gender parallels the biological division of sex into male and female, but it involves the division and social valuation of masculinity and femininity. In other words, gender is a concept that humans create socially, through their interactions with one another and their environments, yet it relies heavily upon biological differences between males and females. The social construction of gender is demonstrated by the fact that individuals, groups, and societies ascribe particular traits, statuses, or values to individuals purely because of their sex, yet these ascriptions differ across societies and cultures, and over time within the same society [4].

There are differing views on gender theory from the perspective of sociologists and theologians. In social science, gender means differences that are not biological and not God's nature. Biological differences are God's nature so it is permanently different from the notion of gender. Gender is behavioral differences between men and women that is socially constructed. The differences that are not God's provisions but are created by humans (not nature) through a long social and cultural process. Sociologists tend to refer to the Nurture Theory where the distinction of relations between men and women is not determined by biological factors and divine nature alone but by the formation and construction of society so that it is not universal and interchangeable. Whereas theologians tend to refer to the belief that gender roles are regulated by God and are not negotiable because it is believed to be God's will.

The Bible gives reasons that strengthen the Theory of Nature:

a) Adam was the main human being created by God, while Eve was only created when Adam needed a suitable match.

b) Women are created as helpers.

c) Men are the heads of women. 
d) Men radiate the image and glory of God directly. While women created from men shine the glory of men and only shine the glory of God indirectly.

The consequence of this interpretation of theological assumptions is that men occupy positions as ordinate and women occupy positions as subordinates.

\subsection{Patriarchy and Marginalization of Women}

For centuries theologies produced and formulated into dogmas/churches and practised in the church, life is discussed by the thoughts, feelings, experiences, struggles, and hopes of men who are highly androcentric of patriarchal culture. Patriarchy comes from two Greek words, the words 'pater' ( $\pi \alpha \tau \eta \dot{\rho})$ and 'archö' $(\alpha \rho \chi \omega)$, which literally translated as 'father's rule' or 'male authority'. According to Nicola Hoggard Creegan and Christine Pohl, that term often refers to political power and male authority in society [5]. The term can also refer to the power of fathers in the family. Literally, the meaning of patriarchy is the father's rule or male authority, where women must obey male. Patriarchy itself has principle that is men must be more dominant in all fields compared to women who become subordinate.

The perpetuation of women's subordination and marginalization based on interpretations of theological assumptions of the Bible is based on the belief and understanding that:

a) God's creation is primarily male, not female. Women do not directly illuminate the glory of God. It is men who shine the glory of God directly.

b) That it was woman caused the fall of man and expelled humans from the Garden of Eden. Therefore, women are considered to be not trustworthy in their decision making.

c) That woman was created as helpers for men. Women were created to fulfill men's interests and needs. This makes the existence of women instrumental and lacks fundamental existence.

The stereotype that is built from this theological assumption is that women label themselves with the title 'helper' but not a helper who has a clear existence but rather an 'invisible helper'. A woman's happiness and success are judged by her success as a helper. Of course, this is closely related to the satisfaction of the party being helped, namely men.

In Ephesians 5: 22-23 it says that "the husband is the head of the wife just as Christ is the head of the church". This statement locks down the role of women as subordinate. Men are placed as superior because men are the heads of women. The command to submit to the husband as to God, can be interpreted as absolute obedience without questioning or debating the decision he made. A stereotype was created that women cannot do anything without men, just as the body cannot do anything without the head. The body can only move in accordance with the commands of the brain. Then women have no power in decision making. As a head, men are blessed with a ratio. Meanwhile, as a body, women are blessed with feelings. Labeling that women are only dominated by irrational feelings, placing women in positions that are not heard. Even if she succeeds in becoming a leader, the rationality of her decisions is often questioned.

The theological assumption interpretation of the book of Genesis says men take priority over women. This is built on the historical religious belief that men are the first to be created, not women. Women are created from men's ribs.

And the LORD God said, "[It is] not good that man should be alone; I will make him a helper comparable to him." (Genesis 2:18, New King James Version).

The stereotype of women created as a helper for men causes excessive workload on women. There is a logical analysis that people who help are stronger than those who are helped, people who are helped are weaker than those who are helping, then women are actually considered to be stronger to bear everything and often problem-solving is imposed on women. Women do not have the right to make decisions, but ironically when there are 
problems in implementing these decisions, women are the ones who bear the solution to the problem.

Amy Blackstones [4] revealed that traditionally, many Western societies believe that women have a more nurturing nature than men. Therefore, the traditional view of gender roles stipulates that a woman in a traditional feminine gender role will be a caretaker of her family by working full time at home (fulltime mother) rather than taking work outside their home. Men, on the other hand, are considered by the traditional view of gender roles to be leaders. That is the traditional view of the role of masculine gender. Therefore, it is recommended that men become the head of their household by providing a living for the family and making important family decisions. While this view remains dominant in many Western societies. The traditions and community beliefs that women's roles are responsible for all domestic work causes women to bear heavier and longer-term domestic workloads. This socialization of gender roles causes women to feel guilty if they neglect their domestic tasks. Women who work outside the home will bear twice the workload.

Another interpretation of the statement 'husband is head and wife is body' is that the blessing always comes from the head down to the body. In this case, a blessing is interpreted as a living. Then the main breadwinner is husband. The wife must learn to depend on her husband for life, believe and pray that God bless her husband's work. The wife must not have the desire to occupy a position as the main breadwinner. Because it is believed that the blessing was given by God through the husband not through the wife, according to the hierarchy of the head down to the body. This is the reason why equal workmen get higher wages because the husband is the main breadwinner. Whereas the wife works to get extra money so it doesn't matter if she is paid less. It is very unfair for women workers, they have worked with double burdens but earn less.

Cassino [6] used a nationally representative, large scale dataset, National Longitudinal Study of Youth, to capture the broad trends and also interviewed 35 young women who worked as babysitters and 25 women who worked in the retail and service sectors in the US. The recent research has shown that the pay gap starts long before these career choices and negotiations are made: teenage girls as young as 14 and 15 are consistently paid less than their male counterparts. This research proves that the wage gap even occurred since adolescence.

\subsection{Feminist Movement}

The impact of women's position as subordinates in which policies are made without regard to women's opinions and needs is the occurrence of discrimination and injustice for women in various fields. Awareness of marginalization and injustice raises social reactions that demand justice and gender equality.

America and Europe are continents dominated by Christianity, where the theological assumptions about gender are very influential on social policies. Women could not vote. A married woman was not a separate legal entity from her husband, and any property or money she owned came under his governance. It was widely believed that women were more emotional than rational, and did not have the intellectual capabilities of men.

Mill [7] argues that if women seem emotional, passive and apolitical, it is because they have been brought up to be so. Mill insists that until society treats men and women equally, it will be impossible to know the natural abilities of women, or whether there are inherent differences between the sexes. Mill claimed a married woman cannot be her husband's true equal unless she has the confidence and sense of entitlement that comes from contributing materially to the support of the family. In order to be partners rather than servants of their husbands, wives must earn an income outside the home. In further explaining her view that married as well as single women should work.

Mill's opinion that it is very important for the dignity of women that they are given the right and ability to earn their own living and support themselves contrary to the gender roles established by biblical gender theology. Biblical gender theology position women as subordinate. And as a subordinate woman must not release dependence on their ordinate. The 
main breadwinner is the husband. The wife must learn to depend on her husband for life, believe and pray that God bless her husband's work. The wife must not have the desire to occupy a position as the main breadwinner. Because it is believed that the blessing was given by God through the husband not through the wife, according to the hierarchy of the head down to the body.

Tong [1] explained both John Stuart Mill and Harriet Taylor Mill believed women needed suffrage in order to become men's equals. They claimed the vote gives people the power not only to express their own political views but also to change those systems, structures, and attitudes that contribute to their own and/or others' oppression. Mill argued in "The Subjection of Women" that if women's rational powers were recognized as equal to men's, then society would reap significant benefits and a multitude of very happy women. The writings helped smooth the entrance of many poor as well as rich women into the public world. In 1848, three hundred women and men met in Seneca Falls, New York, and produced a Declaration of Sentiments and twelve resolutions. Modelled on the Declaration of Independence, the Declaration of Sentiments stressed the issues Mill and Taylor had emphasized in England, particularly the need for reforms in marriage, divorce, property, and child custody laws.

Betty Friedan shocked the United States when her book "The Feminine Mystique" became a bestseller in 1964 in the category of non-fiction books. He is considered as the trigger of the second wave of feminist movements in the country. In those days, the media in the United States confirmed the image of happy women as housewives and instilled the message that women's fulfilment was only achieved by being a wife and mother. Betty Friedan called it feminine mysticism. He revealed that reality in society is the opposite. She said about the problem that has no name of the wives and housewives; they are not happy even though they live in material means. Friedan encouraged women to self-actualize. It also offers education and meaningful work as a way for women to avoid this feminine mystic trap in the existentialist feminist movement [8].

America and Europe are continents dominated by Christianity, where the theological assumptions about gender are very influential on social policies. Mary Daly (1985) realizes that the perpetuation of women's subordination and marginalization based on interpretations of theological assumptions of the Bible. The transcendent God who appears in Judaism, Islam, and especially Christianity is a God who is very powerful to determine the pattern of relations between humans. Her argument begins with a reading of Christian theology. Dale questions why God is portrayed as a male figure. From this critique, Daly proceeds to argue for a feminist theology or a theology of feminism. She reveals the very harmful connection between patriarchy and Christianity. She would argue, the two cannot be separated. She sought to legitimize the argument for the theology of feminism and also answered the need for feminism to answer Christianity critique [9].

\subsection{Men Social Reaction}

In reality, feminism represents a diversity of viewpoints. But some people believe that feminism consists of a set of rigid rules and dictates the women must be antagonists toward men. Feminist thought received a lot of criticism, especially from religious figures. A statement long attributed to television evangelist Pat Robertson has him describing the "feminist agenda" as "a socialist, anti-family political movement that encourages women to leave their husbands, kill their children, practice witchcraft, destroy capitalism and become lesbians" [10]. The accusation is not without reason. Rosemarie Tong tells the story of Mary Wollstonecraft's, who twice attempted suicide, refused to marry but had two children out of wedlock. John Stuart Mill and Harriet Taylor lead an unusual life. They met in 1830 when Harriet Taylor was married to John Taylor and was the mother of two sons. Harriet Taylor and Mill were immediately attracted to each other, both intellectually and emotionally. During the years before the death of John Taylor, Harriet Taylor and Mill routinely met each other for dinner and often spent the weekend together along the coast of England. Given their personal situation, Mill and Taylor's focus on topics such as marriage and divorce is not surprising [1]. 
Although feminist thought received a lot of criticism, especially from religious figures, feminist thought began to influence primarily to fight for women's rights legally. Raquel Fernández [11] explores the empirical validity of theoretical predictions by using crosscountry variations in the US when married women acquire property and get rights between 1850 and 1920. The basic hypothesis is that the process of development exacerbated the tension in men's conflicting interests as husbands versus fathers, ultimately resolving them in favour of the latter. As husbands, men stood to gain from their privileged position in a patriarchal world whereas, as fathers, they were hurt by a system that afforded few rights to their daughters. The model predicts that declining fertility would hasten reform of women's property rights whereas legal systems that were initially more favourable to women would delay them. This research proves that not all men feel threatened by feminists.

According to Matlin, there are three men's social reactions: profeminist, mythopoetic movement, and religious-oriented approach [12]. Profeminist focuses on how traditional gender hurts both men and women. But, other men's movements are a reaction against the women's movement and seek to restore traditional female and male roles. These have attracted more men than profeminist movements. Two such movements are the mythopoetic movement and the Promise Keepers. Both of these movements view men and women as fundamentally different. The Bible is used to justify the differences between women and men and the natural state of men's superior position over women, especially in the Promise Keepers movement. According to the Promise Keepers website [13], Promise Keepers founded in 1990 by Bill McCartney. Promise Keepers is one of the biggest spiritual movements in the history of Christianity. But Matlin said "We must carefully examine their principles because these groups typically want to reduce the rights of women".

Another movement based on masculinity is the Christian Men's Network. Founded by Edwin Louis Cole and his family in 1979, CMN has made his classic book "Maximized Manhood". This movement continues today under the leadership of Paul Cole, Dale C. Bronner in Atlanta, Robert Barriger in Peru, Eddy Leo in Indonesia, J. Doug Stringer in Houston, and other key men around the world more than 210 countries [14]. Promise Keepers founder Bill McCartney has credited Cole with paving the way for his organization and other men's ministries. "For me personally, he's a mentor," McCartney told the Dallas Morning News in a 1998 interview written back in Los Angeles Times [15].

In chapter one of "Real Man", Cole wrote about a current crisis in manhood and are trying to correct it. Cole shows a headline in the Boston Globe read: "Wanted: Some Stouthearted Men". The article began with the question "What's wrong with America?" and gave this answer: "Lousy leadership. Not just in government or politics, but business and labour, service and manufacturing, education and other big institutions, and the media, too." Cole has an opinion that crisis in leadership and productivity basically from a crisis in manhood and The U.S. is not the only country suffering such problems but scores of problems confront men in every nation under the sun. And Cole states that one of the causes is Feminists rage against maleness, creating a new perception of the word man, cry out to replace gender-specific terms with neuter terms and this conflicts cause men to throw away their identities, become ineffective, sterile lazy and no wonder men today are confused about manliness. Cole gives the solution for the masculinity crisis: "the essence of real manhood is found not in how a man looks or in what a man does but in who a man is" [16].

\section{Conclusion}

From this study we can understand that patriarchy is a system and culture based on the interpretation of biblical assumptions based on the Bible where men are the heads of women. The conditions and problems arising from a patriarchal system of rationale, stereotypes, systems, culture, rules and patriarchal practices that marginalize women which are then opposed by feminism Feminists by arguing on the theory of nurture that gender is the result of 
social reconstruction. Feminist thought received a lot of criticism and reaction. Some men support feminists but some against feminists by defending patriarchy as gender based on theology interpretation.

\section{References}

[1] R. Tong, Feminist Thought: A Comprehensive Introduction. Colorado: Westview Press, 2009.

[2] R. J. Stoller, "Sex and gender: The development of masculinity and feminility," Karnac LTD, 1968.

[3] A. Utaminingsih, Gender dan Wanita Karir. Universitas Brawijaya Press, 2017.

[4] A. Blackstone, "Gender Roles and Society. (J. R. Miller, R. M. Lerner, \& L. B. Schiamberg, Eds.) Human Ecology: An Encyclopedia of Children, Families," 2003, pp. 335-338.

[5] N. H. Creegan, Perempuan di Perbatasan. BPK Gunung Mulia, 2010.

[6] Y. B. Cassino, "How the Pay Gap Starts While We are Still Teenagers?," $b b c$, 2018. [Online]. Available: https://www.bbc.com/worklife/article/20180601-how-the-pay-gap-starts-when-weare-teenagers.

[7] J. S. Mill, The subjection of women, vol. 1. Transaction Publishers, 1869.

[8] B. Friedan, The feminine mystique. WW Norton \& Company, 2010.

[9] M. Daly, Beyond God the father: Toward a philosophy of women's liberation. Beacon Press, 1985.

[10] Robertson, Letter Attacts Feminis. The Associated Press, 1992.

[11] R. Fernández, "Women's rights and development," J. Econ. Growth, vol. 19, no. 1, pp. 37-80, 2014.

[12] M. W. Matlin, "The Psychology of Women. Wadsworth/Thomson,” 2004.

[13] "No Title.” [Online]. Available: https://promisekeepers.org/promise-keepers/about-us/.

[14] "No Title." [Online]. Available: https://www.christianmensnetwork.com/pages/about-us.

[15] E. Cole, "Led Christian Men's Network." [Online]. Available: https: //www. latimes. com/archives/la-xpm-2002-aug-31-me-cole31-story.html.

[16] E. L. Cole, "Real Man, Watercolor Books," 1992. 